〈研究ノート〉

\section{日中間のシイタケ生産費の 比較分析}

$\begin{array}{lll}\text { 古 } & \text { 塚 } & \text { 秀 } \\ \text { 甘 } & \text { 長 } & \text { 飛 }\end{array}$

\section{1.はじめに}

シイタケ栽培は，1980年代前半までわが国の中山間 地域において農家の現金収入源として大きな役割を果 たしてきた．ところが，「円高」傾向を示す'87年から 乾シイタケの輸入が，また，'91年から生シイタヶの 輸入が急増している.'94年の輸入量は乾シイタケで $7,804 \mathrm{t}$, 生シイタケで $26,320 \mathrm{t}$ となっている1). これ は急増する前年と比較して63倍（乾シイタケ）扣よ び29倍（生シイタケ）の輸入量である．この輸入によ って国内価格は低迷し，栽培農家戸数の減少や規模縮 小がみられる。したがって，国内生産量は减少傾向を 示している.すなわち, '94年の国内生産量は乾シイ タケが $8,321 \mathrm{t}$, 生シイタケが74,294 $\mathrm{t}$ であるが3), 生 産量はピーク時に比べて $50 \%$ (乾シイタヶ $)^{4)}$ まは 10\%（生シイタケ）减少している. 乾シイタケ生産量 の减少傾向が著しいのは国際競争の結果，香港市場で シェア第 1 位の座を中華人民共和国(以下中国とい5) 産に奪われたことも原因している．日本の輸入量の97 \%は中国産が占めている，中国産が急増した背景に は,「円高」以外に中国政府の振興策（「星火政策」） があるが，安価で，しかも品揃えがしやすいことが急 増の要因となっている，換言すれば，中国産は国際競 争力が強いといえるが，これは生産費と密接に関係し ている5)。したがって，国際競争下のシイタケ栽培で は生産費の比較が重要である．生産費の国際比較は， 米や畜産物についてはかなり行われているが，今日輸 入が急増しているシイタケやブロッュリー, ニンニク などの野菜については行われていない。

本稿の目的は，第 1 K，日本と中国のシイタケ生産 費を比較することによって生産費格差の要因分析をす ることである．第 2 に，要因分析結果から日本のシイ タケ栽培における生産費低減の可能性とその方向を明 らかにすることである．第 3 に，中国のシイタケ栽培
の将来性を検討することである。これらの目的のため に中国のシイタケ主産地である浙江省慶元県の菌床栽 培農家16戸に聴き取り調査を行った．詳しい生産費格 差の要因分析方法は後述するが，標準原価計算におけ る原価差異分析を用いている.

\section{2. 調查地の概況 ${ }^{6)}$}

まず第 1 に自然的立地条件であるが，慶元県は浙江 省の西南部にあって南は福建省と接している，上海か ら南南西に775 km の位置にある，林野率 (85\%) に 基づくと日本でいら山村に該当する．交通手段はバス やトラックであって鉄道はない。緯度（27度25分から 27度51分）でみると奄美大島と沖縄の中間くらいに位 置しているために平均気温 $\left(17^{\circ} \mathrm{C}\right)$ は西日本より高 いが，昼夜の温度格差（平均 $10^{\circ} \mathrm{C）} \mathrm{が大きい。この}$ 温度格差がシイタケの発生に好条件となっている。

第 2 にシイタケ生産量である.'92年の中国の総生 産量（乾シイタケ換算）は29, $800 \mathrm{t}$ であるが，このう ち慶元県のシイタヶ生産量（同）は6,886 t である.

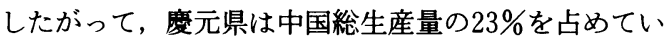
る. 慶元県のシイタケ生産は乾シイタケが中心であり, '86年に $396 \mathrm{t}$ であった乾シイタケ生産は, '94年には 9 , $860 \mathrm{t}$ まで増加している. しかし，'92年以降年平均増 加率は低下している. 生シイタケ生産は’90年に開始 されて，当初は50t の生産量であったが，'93年には $1,000 \mathrm{t}$ の生産量になっている。しかし，'94年には600 $\mathrm{t}$ まで減少している.'92年の慶元県の農業生産額は31 億 2,000 万円（1 元=12円で換算, 以下同じ）である が，この5ちシイタケ生産額（21億6,000万円）が69 \%を占めている．このことからシイタケは大きな基幹 作目であることがわかる．

第 3 にシイタケ栽培農家戸数である，'93年のシイ タケ栽培農家戸数は 30,000 戸である。このうち菌床栽 培農家が28,000戸であり，残りは原木栽培農家であ る. 立地条件の良い水田で菌床栽培が行われて，原木 栽培は徒歩で 2 時間程度山奥に入ったところで行われ ている．原木栽培はほだ木の育成期間が長期になるた めに資金の回収が遅い。このために原木栽培農家戸数 は減少している。' 92 年の資料によると慶元県の人口 は 185,604 人である． 1 戸当たり 4 人家族とすれば戸 数は46,401戸となる. 県内の農家戸数は 38,000 戸であ るから県の $82 \%$ は農家であり，さらに農家の79\%はシ イタケ栽培に従事していることになる. シイタケ栽培 に関連して種菌の生産に464戸が，県外のシイタケ栽 培に7,000戸が7), シイタケ乾燥専門に145戸が，木材 
を粉砕するオガ生産に17戸が，原材料の供給に419戸 が、シイタケ流通に2,500戸以上が従事している。こ のよらにシイタケ栽培の関連産業が発達して拈り, シ イタケ栽培が県の振興に大きな役割を担っている。 くに, シイタケ流通に関しては, 年間取扱量が 4,284 t（'92年）におよぶ世界最大の乾シイタケ市場（慶元 香菇市場）がある。

\section{3. 経営構造と栽培形態}

生産費は経営構造や栽培形態に大きく規定されてい る.したがって，ここでは調査農家16戸のデータに基 づいてシイタケ栽培農家の経営構造と栽培形態を明ら かにする．な拈，栽培形態の分類方法として 3 つを考 えている.1つは原木栽培と菌床栽培といら分類であ る. 2 つは乾と生シイタケの販売金額と生産量の割合 に基づく分類であり， 3 つは栽培方法による分類であ る.

\section{(1) 経営構造}

まず経営形態であるが家族経営である．第 2 亿経営 部門組織である，調查農家（16戸）をみると生産部門 としてはシイタヶ栽培の他に稲作 (14戸), 野菜作 (16戸), 雑穀作 ( 6 戸), い子作 ( 9 戸), 果樹 ( カン) 作（2戸）がある。また，養豚を行っている農
家(14戸)が多い，生産物の用途をみると米 $(25,756 \mathrm{k}$ g) は販売 $12 \%$, 家計仕向 $69 \%$, 物納 $5 \%$, 家畜飼料 14\%であって，販売農家はわずか 2 戸である. 他の生 産物はすべて家計仕向用や家畜飼料用である. したが って，注とんどのシイタケ栽培農家の現金収入源はシ イタケ栽培部門だけである。この現金収入によって家 族 4 人の生活をまかなっている. 調査農家 1 戸当たり 耕地面積は水田 $25.2 \mathrm{a}(1$ ム $-=6.67 \mathrm{a}$ で換算, 以下 同じ), 畑 $5.7 \mathrm{a}$, 果樹園7.1 a である8).この5ち水田 $1.2 \mathrm{a}$, 果樹園 $6.7 \mathrm{a}$ は, 他農家より借り入れている. この他に 1 戸当たり山林 $149.4 \mathrm{a}$ を所有している.

第 3 にシイタケ栽培部門（菌床栽培）の規模である が，'92年の総生産量 $(6,886 \mathrm{t})$ から逆算すると 1 戸当 たり拉よそ 3,600 個9 の規模となる。調査農家の概要 を表 1 亿示しているが, 平均規模は乾シイタケ生産で 10,014個，生シイタケ生産で6, 760個であって県平均 と比較するとかなり大規模である.

第 4 亿労働力であるが, 調査農家16戸のシイタケ栽 培農家は平均 4 人家族で，5ち2.7人が年間 300 日以上 農業に従事している.農業労働力は主にこの家族労働 カであるが，シイタケ栽培では培地材料の調整や培地 の詰込み作業を中心に雇用労動をかなり導入してい る. 雇用労働日数は総労働日数（1 戸当たり平均 447.

表 1. 中国調査農家のシイタケ栽培の概要

\begin{tabular}{|c|c|c|c|c|c|c|}
\hline 農家番号 & 規 & 生 & 販売手取金額 & 栽 培 形態 & $\mathrm{kg}$ 当たり販売手取単価 & 1,000 個当たり生産量 \\
\hline & 個 & $\mathrm{kg}$ & 元 & & 元 & $\mathrm{kg}$ \\
\hline 1 & 17,000 & $1,356.0$ & 41,954 & 乾 専 & 31.2 & 79.8 \\
\hline 2 & 12,000 & $1,000.0$ & 31,789 & 乾 専 & 32.0 & 83.3 \\
\hline 3 & 10,000 & 670.0 & 19,000 & 乾 専 & 27.7 & 67.0 \\
\hline 4 & 11,000 & 828.0 & 23,940 & 乾 専 & 29.0 & 75.3 \\
\hline 5 & 8,500 & 502.5 & 16,100 & 乾 専 & 32.0 & 59.2 \\
\hline 6 & 6,600 & 468.0 & 14,050 & 乾 専 & 30.1 & 70.9 \\
\hline 7 & 6,500 & $2,736.0$ & 8,931 & 生 専 & 3.3 & 420.9 \\
\hline 8 & 5,200 & 162.0 & 6,161 & 乾 専 & - & - \\
\hline 9 & 9,000 & $3,045.0$ & 12,000 & 生 専 & 4.0 & 338.3 \\
\hline 10 & 7,000 & $2,933.0$ & 10,300 & 生 専 & 3.5 & 419.0 \\
\hline 11 & 5,000 & 313.0 & 10,980 & 乾 専 & 36.0 & 62.6 \\
\hline 12 & 4,100 & $2,030.0$ & 7,000 & 生 専 & 3.5 & 495.1 \\
\hline 13 & 5,000 & 262.5 & 5,760 & 乾主生従 & - & - \\
\hline 14 & 5,000 & 428.0 & 12,000 & - & - & - \\
\hline 15 & 7,200 & $4,025.0$ & 14,000 & 生 専 & 3.5 & 559.0 \\
\hline 16 & 5,000 & 142.0 & 6,800 & 乾 専 & - & - \\
\hline
\end{tabular}

資料：’93年分聴き取り調査結果.

注：1）栽培形態については本文脚注12）を参照されたい。

2)「生産量」「1,000個当たり生産量」は, 栽培形態が11「乾専」「乾主生従」では乾シイタヶ換算を, (2)「生専」「生主乾 従」では生シイタケ換算をしている.生産量の換算は歩留まりを $10 \%$ としている．また，「 $\mathrm{kg}$ 当たり販売手取単価」 は乾シイタヶ（「乾専」「乾主生従」）または生シイタヶ（「生専」「生主乾従」）を示す。

3）「一」は，「栽培形態」では該当なしを，「kg 当たり販売手取単価」「1,000個当たり生産量」では調査が不十分なため に生産費比較の要因分析対象から除いていることを示す. 
0日）の $17 \%$ に相当する ${ }^{10)}$.

\section{（2）栽培形態}

日中間の生産費格差の要因分析のために栽培形態は 慶元県だけでなく日本についても述べておきたい。

慶元県における栽培形態は，上述した栽培農家戸数 からわかるよらに菌床栽培が主である。これは中国全 体を見ても同じである.このことと慶元県がシイタヶ 主産地11)であることから慶元県に打ける栽培方法は中 国の代表的なるのとい方る.販売金額と生産量に基つ いて調査農家を分類すると表 1 のよらになる．乾と生 シイタケ両方を生産する栽培形態12) は少ない，次に， 栽培方法であるが菌床栽培では 2 つの生産過程があ る. 1 つは菌床をつくる過程であって本稿ではこれを 培養過程という．培養過程の作業には培地材料調整・ 詰込み，殺菌，接種，袋作り，培養管理がある。1， 000個当たり労働日数は，それぞれ8.2日，4.4日，2.9 日，1.7日，3.0日である ${ }^{13)}$. 培地材料調整から袋作り までを 2 月から 3 月にかけて行ら，その後, 屋内で培 養管理を 9 月または10月まで行って菌床を作る。した がって，培湌過程は 8 カ月となる．培屋管理中は水田 では稲を栽培している. す5 1 つの生産過程は培養し た菌床を用いて発生舎内でシイタケを生産する過程で あって，本稿ではこれをシイタケ生産過程といら．シ イタケ生産過程の作業には袋はずし, 菌床移動, 散水 ・浸水, 収檴・乾燥・出荷作業がある. 1, 000個当たり 労働日数 ${ }^{14)}$ は，乾シイタケ生産ではそれぞれ0.9日， 1.6日，4.9日，37.3日である.生シイタケ生産では1. 0日，4.0日，12.5日，14.3日である．袋はずしと屋内 から発生舎までの菌床移動は 9 月から10月にかけて行 う. 発生舎内では畧を作って菌床を置きビニールで覆 って，必要なときに畧の谷に水を入れてその水で散水 ・浸水している. 散水・浸水は 9 月から 4 月にかけて 2 回程度行5. 収穫・乾燥・出荷作業は10月から 4 月ま で行う。したがって, シイタケ生産過程は 7 カ月とな る. 以上の栽培方法は乾シイタケ生産も生シイタケ生 産も同じである．両者の違いは乾燥作業の有無であ る. 乾燥方法は晴天のときには 3 時間程度天日乾燥を してから乾燥機で乾燥する. 雨天のときは直接乾燥機 に入れる. 乾燥機の燃料は薪である．上述の作業の他 に発生舎の組み立てと取り壊しの作業がある．材料は 支柱に竹や木材を, 周囲と屋根には背丈の長いアシや ススキなどの草を利用している. 竹や木材は 3 年間利 用している．毎年 9 月または10月に水田に発生舎を組 み立てて，稲作が始まる翌年 4 月から 5 月に取り壊し ている農家が多い。しかし，稲作をしないで 1 年中発
生舎を水田にそのままの状態にしている農家もある。

日本のシイタケ栽培は, 原木栽培と菌床栽培がある が，原木栽培の栽培形態には「乾専」「乾主生従」「生 主乾従」「生専」の 4 形態がある. 立地条件と経営者 能力が栽培形態の移動を制約しているが，長期的には 収益性の高、栽培形態への形態移動がみられる15)。菌 床栽培は「生専」の形態だけであり乾シイタケは生産 しない。近年, 生シイタケ生産では原木栽培が減少し て菌床栽培が増加している. 栽培方法であるが原木栽 培では, 原木から完熟ほだ木を育成するほだ木育成過 程と, 完熟洼だ木を用いてシイタケを生産するシイタ ケ生産過程の 2 つの生産過程がある。注だ木育成過程 の作業には，伐採・玉切り・搬出，植菌・伏込久，育 成管理があるが，都市近郊の平坦地で行ら「生専」「生 主乾従」では原木を玉切り購入するために伐採・玉切 り・搬出作業はない，原木の伐採作業は10月から年内 に, 植菌・伏込み作業は 3 月と 4 月に行ら. その後, 育成管理を翌年の 10 月まで行ら。ほだ木の育成期間は 2 年であるが，近年，この育成期間を短縮させるため に原木 1 本当たりに従来の倍以上の量を植菌する多孔 植菌が普及している，とくに，「生専」「生主乾従」の 施設型栽培農家に普及している。この技術によって植 菌した年内にシイタケが発生可能となる. シイタケ生 産過程の作業は露地型栽培の「乾専」「乾主生従」と パイプハウス, 浸水槽などを利用して行ら施設型栽培 の「生専」「生主乾従」とでは異なる。露地型栽培の 作業にはほだ降し、ほだ場管理, 収檴・乾燥, 包装・ 出荷がある.ほだ降しは植菌して 2 夏経過後の 10 月に 行5. それ以降 4 年間秋から春にかけてシイタケが発 生する。したがって，ほだ木の用役期間は 4 年であ る. 施設型の生シイタケ生産では 1 日当たり 100 本か ら200本のほだ木を浸水して，その後八ウス内へほだ 木を移動させてシイタケを収檴し, 一度収穫が終了す れば休湌場所へほだ木を移動させる．そこで一定の休 養期間後に, 再び, [浸水槽への移動一浸水一八ウス への移動一収穫一休養場所への移動一休養といら一 連の作業を繰り返し行う。施設型栽培ではこの発生作 業を注注毎日行って周年出荷している. 汪だ木の用役 期間は 2 年から 3 年であるが, 多孔植菌の場合はほだ 木の年間浸水回数が増えて用役期間が半分に短縮され る.

菌床栽培は大きく分けると HK 方式とK方式があ $3^{16)}$. HK 方式は, パイプハウス, 暖房機, 冷房機 などを利用して行ら施設型栽培であるが，設備投資は K方式に比べて少ない，一方，K方式は鉄骨ハウスに 
空調設備を設けて行ら空調施設型栽培である。また， HK 方式では, 自家培養型と菌床購入型がある.K万 式は菌㦿購入型である. HK 方式の自家培養型では培 地作りは年 2 回行う．培㽰期間は拉よそ 4 カ月で, 1 回目が 1 月から 4 月で, 2 回目が 8 月盆過ぎから 12 月 である、シイタケ生産期間は 4 カ月から 5 カ月で, 1 回目の菌床が 8 月から 12 月で, 2 回目の菌床が 1 月か ら 4 月である ${ }^{17)}$. シイタケ生産過程では「5 日から 7 日間発生, 10 日間収檴, 15 日間休養」の 1 サイクル30 日を 4 回から 5 回繰り返す. 発生操作として菌床を漫 水または散水する. 周年出荷しているが冬場に生産の ウェートがある. シイタケ生産過程の作業は菌床購入 型も同じである.K方式では空調施設によって周年出 荷している. 菌床 1 個当たりシイタケ生産期間は 6 力 月から 7 カ月である. 毎月一定量の菌床を購入して周 年で生シイタケ生産を行ら. 発生操作として 1 日に 30 分から 1 時間の散水を行5. 日本の菌床栽培では, 次 の 3 つの理由によって自家培養型は少ない，すなわ ち, その 1 として培㽰技術が未熟な場合, 雑菌が混入 する危険性が高いこと, その 2 として培養施設への投 資が大きいこと, その 3 として培養過程とシイタケ生 産過程に括いて労働の競合問題が発生することであ る.

ここで 2 力国の栽培形態の違いをまとめてみると, 中国は自家培養型の菌床栽培が主である. 発生舎を利 用するが，乾または生シイタケのどちらかを冬場の気 象条件を利用して生産する露地型栽培である.これに 対して日本の原木栽培では栽培農家は乾と生シイタケ 両方を生産して栽培形態を移動させる。乾シイタケは 露地型栽培で冬場に生産される. 生シイタケ生産は施 設型栽培が主であって，この栽培方法によって生シイ タケが周年出荷されている. また, 菌床栽培では菌床 購入型が多いが, 生シイタケだけを施設型栽培によっ て1年中生産している.

\section{4 . 生産費格差の要因分析}

本節の分析対象農家について述べておさたい，生産 費格差の要因分析を正確に行らために「乾専」と「生 専」の栽培形態を分析対象にしている.なぜなら, 乾 と生シイタケの両方を生産する「乾主生従」や「生主 乾従」の栽培形態では，2つの生産物に費用を配賦し なければならない，配賦といら手続きをとるだけ正確 性を欠くことになる。 また，中国の調査農家は規模が 大きくて専門化の利益を得ていると考兄られる．例兄 ば，表 1 に示す 1,000 個当たり生産量がある。一般に
生産量の目標は培地重量 $(2 \mathrm{~kg})$ の $30 \%$ とされるが, 乾 シイタケ生産では歩留まり10\%で乾シイタケ換算する と $30 \%$ 以上の 1,000 個当たり生産量を示して, 生シイ タヶ生産では $30 \%$ \%回っているがかなり高い水準に ある. したがって，日本でも大規模で高い生産技術を もった農家を抽出している，換言すれば，生産技術は $\mathrm{kg}$ 当たりの販売手取単価と生産費に集約されるが, 前者を後者があまり上回らない農家を 2 力国で抽出し ている

なお，日本の乾シイタケ生産では財)日本きのこセン ターの記帳農家を分析対象にしたことによって多数の 生産農家データの利用が可能であった。他方, 生シイ タケ生産では栽培方法が多様化しているために近畿地 方の主産地である奈良県を取り上げて，栽培方法を(1) 原木栽培では施設型の玉切り購入による多孔植菌に, (2)菌床栽培ではK方式（菌床購入型）に限定して聴き 取り調查を行った. したがって, 乾シイタケ生産に比 べて分析対象農家戸数が少なくなっている.

\section{(1) 経営成果比較}

生産費格差の要因分析に入る前に, 2 力国間の経営 成果を比較して扰きたい，経営成果を表 2 亿示してい る. 第 1 亿乾シイタケ生産であるが，原木栽培と菌床 栽培の違いがあるために 1,000 本（個）当たりの指標 は比較しないで, まず, $\mathrm{kg}$ 当たりの販売手取単価と 生産費を比較すると 2 指標とも10倍の格差がある。 た， 2 力国ともわずかであるが， $\mathrm{kg}$ 当たりの生産費 が販売手取単価を上回っている. 次に，1 日当たり家 族労動報酬には38倍の格差があるが，中国の 1 日当た り家族労働報酬161円は，農業臨時雇貨金の男180円， 女144円や一般サラリーマンの年収 54,000 円と比較し てもあまり見劣りしない18).

第 2 亿生シイタケ生産である. その 1 として, 日本 の原木栽培と比較する. 上述の乾シイタケ生産と同じ 理由によって, まず, $\mathrm{kg}$ 当たりの販売手取単価と生 産費を比較するが16倍から 21 倍の格差がある. 1 日当 たり家族労働報酬にも格差がかなりある.中国の生ン イタケ生産の 1 日当たり家族労働報酬は乾シイタケ生 産を下回っている。これは次のことが原因している. すなわち，生シイタケ生産の 1,000 個当たり生産量を 歩留まり $10 \%$ で乾シイタケ換算すると，それは乾シイ タケ生産の 1,000 個当たり生産量を下回っている，1， 000個当たり生産量が低いのは生シイタケ生産を開始 して歴史が浅くて，生産技術が十分に確立していない ためである.

その 2 として，2 カ国間の菌床栽培を比較してみ 
表 2 . 経営成果比較

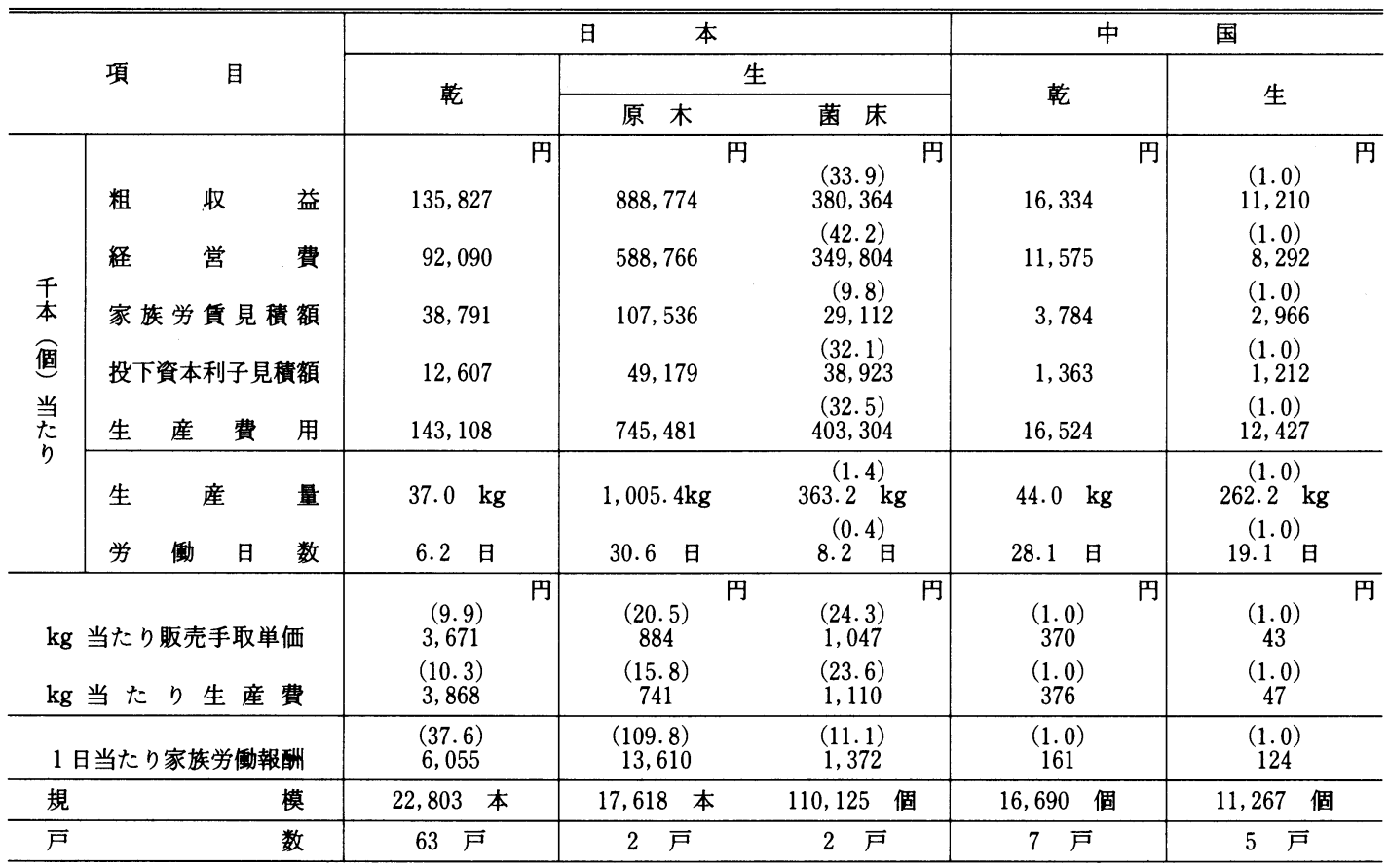

資料：(財)日本きのこセンター経営分析結果 ('90年度分〜'92年度分), ' 93 年度分聴き取り調査結果.

注 : 1)「日本」の「乾」は財)日本きのこセンターの’90年度分から’92年度分の経営分析結果に基づいて’93年度分の経営成果を 推定したものである. また,「生」は奈良県の聴き取り調査結果である.

2) 中国は16戸の調査農家の5ち正確に経営成果まで算出できた「乾専」「生専」の栽培農家の平均値を示す。為替レート は 1 元 $=12$ 円としている.

3）家族労貨見積額は 1 時間当たり日本の男子 900 円，女子 650 円で，中国の男子 22.5 円，女子 18 円である．また，投下資 本利子見積額は投下資本額に日本が $7 \%$ ，中国が $17 \%$ の利率を見積もって算出している.

4）日本の菌床栽培の培地重量は 1 個当たり $1.2 \mathrm{~kg}$ で, 中国は $2.0 \mathrm{~kg}$ である. したがって, 表では日本と比較するために 「千本（個）当たり」の各項目と「規模」は中国の数値を $1.2 \mathrm{~kg}$ 換算している。また，「中国」の「千本（個）当たり」 はシイタケ生産過程のものである．したがって，「経営費」には培養過程の生産費用（菌床価額）を含んでいる.

5）「原木」は原木栽培を,「菌床」は菌床購入型の菌床栽培を指している.

6）乾シイタケ生産を含めた原木栽培の「1日当たり家族労働報酬」はほだ木育成過程を含めたシイタケ部門全体の数値 である.「中国」の「1日当たり家族労働報酬」は培養過程を含んでいる.

7）「経営費」には支払い利子を含むが，「生産費用」を算出する場合には支払い利子は投下資本利子見積額に含んでいる。

8）（）内は中国を基準（1.0）とした格差を示す. 格差を算出して意味のある箇所をあらわしている.

る. 1,000個当たり粗収益, 経営費, 生産費用に32倍 から42倍の格差がある．ただし，1，000個当たり労動 日数は 0.4 倍の格差となって日本が中国に比べて少な い.このために 1,000 個当たり家族学賃見積額の格差 は相対的に小さい，物的生産性を示す 1,000 個当たり 生産量は日本が高い. $\mathrm{kg}$ 当たりの眅売手取単価と生 産費には24倍の格差があるが， 2 力国とも $\mathrm{kg}$ 当たり の生産費が販売手取単価をわずかに上回っている，1 日当たり家族労働報酬には11倍の格差がある.

\section{（2）生産費格差の要因分析}

1）分析方法 上述したように 2 力国間には生産費 格差がかなりある．この生産費格差の要因分析方法と
しては標準原価計算に批ける原価差異の分析方法を用 いる.この分析方法は原価の標準, すなわち標準原価 を標準単価と標準消費数量を乗じることによって設定 して, 実際消費単価と実際消費数量を乗じた実際原価 と比較して，その差異を分析することによって原価管 理に役立てるのである. 原価差異（実際原価一標準原 価）は価格差異（(実際消費単価一標準単価）×標準 消費数量）と数量差異（(実際消費数量 - 標準消費数 量） ×標準単価）および混合差異（(実際消費単価一 標準単価） $\times$ (実際消費数量一標準消費数量 $) ）$ 飞分 けられる.一般的に混合差異は価格差異のなかに含め られて計算される。これは価格差異が管理不可能な性 
格，すなわち経営外部の要因によって発生することが 多いのに対して，数量差異は管理可能な性格を持って いて原価管理ではこの数量差異を厳密に把握する必要 があるためである20).

今日まで生産費の国際比較の成果が十分に得られて いない大きな理由として，生産費格差が要素投入量の 差に起因するのか，要素価格の差に起因するのかを識 別することのできる情報がそしいこと年があげられ る. しかし，上述したよらな原価差異の分析方法を用 いることによってこの問題は解決できる．そこで本稿 では，まず 2 力国間の $\mathrm{kg}$ 当たり生産費の格差を費目 別に求めて, $\mathrm{kg}$ 当たり生産費（全体）の格差に対す る費目別格差の寄与度を算出する．次に寄与度が大き い費目について格差を可能な限り価格差異と数量差異 および混合差異に分けて分析をする．この場合，標準 原価計算に搢ける原価差異を格差と呼ぶことにして, 実際原価 $\left(\mathrm{P}^{\mathrm{J}} \mathrm{Q}^{\mathrm{J}}\right)$ ，実際消費単価 $\left(\mathrm{P}^{\mathrm{J}}\right)$ ，実際消費数量 $\left(\mathrm{Q}^{\mathrm{J}}\right)$ に日本の数值を, 標準原価 $\left(\mathrm{P}^{\mathrm{C}} \mathrm{Q}^{\mathrm{C}}\right)$, 標準単価 $\left(\mathrm{P}^{\mathrm{C}}\right.$ )，標準消費数量 $\left(\mathrm{Q}^{\mathrm{C}}\right)$ に中国の数值を当てはめる．そ して, 価格差異, 数量差異, 混合差異を $\mathrm{kg}$ 当たり生 産費格差で除して $\mathrm{kg}$ 当たり生産費格差に対する各差 異の寄与度を算出する．このことによって $\mathrm{kg}$ 当たり 生産費の格差要因がどの費目であり，しか子価格差異 によるものか数量差異によるものかが明確になって， 生産費低減のためにはどこにその大きな可能性がある のか，あるいはどの点の改良が効果を生みやすいかの 情報が得られる22)。な拉，菌床栽培の菌床価額格差に ついても $\mathrm{kg}$ 当たり生産費格差の要因分析と同じ方法 で分析する.

これまでの農畜産物生産費の国際比較の研究成果と しては, 辻井氏23), 生源寺氏 ${ }^{24)}$, 稲本氏 ${ }^{25)}$ の成果があ る.このらち生源寺氏のものを除く研究成果は生産費 の費目別格差を求めて，それと生産技術とを結び付け て説明するにとどまっている. 生源寺氏の研究成果で は, 生産費の費目別格差を数量と価格および残差の 3 要因に分解して緻密な分析を行っている. しかし，テ イラー展開によって求めた第 3 項目の残差については 「ストレートな解釈が困難である」26) としている．本 稿の分析方法によって求めた各差異の寄与度は生源寺 氏のテイラー展開によって求めた結果と同じである が，生源寺氏の第 3 項目に混合差異といら解釈を与え ることができている．また，原価差異の分析方法の方 が生源寺氏のようにテイラー展開によって 2 次以上の 項を無視するよりも明解である。ただし，費目別に数 量と単価がわかっていなければ，本稿の原価差異分析
を行らことができない，全費目を数量と価格に分けて 聴き取り調査をすることは不可能である。したがっ て, 重要な費目に限って要因分析を行らことになる. 重要な費目とは生産費格差に大きく寄与している費目 であるが，費目によっては数量差異と価格差異の符号 が反対になりプラス・マイナスが打ち消し合って生産 費格差に寄与していないものが生じる．このような費 目も重要であるが，聴き取り調査では残念ながらわか らない。ここに聴き取り調査の限界がある.

2 ) 菌床価額 日本では菌床を購入する場合が多い のに対して, 中国では自家培養している. 日本での購 入価格はメーカーによって異なるが $\mathrm{HK}$ 方式の $2.5 \mathrm{~kg}$ 培地で250円から270円で，K方式の $1.2 \mathrm{~kg}$ 培地で 220 円である．中国では $2.5 \mathrm{~kg}$ 培地換算でおよそ 17 円の 菌床価額となる (表 3 参照). 表 3 では奈良県の 2.5 $\mathrm{kg}$ 培地の菌床を自家培養している生産農家と中国を 比較している．菌床価額の格差に対する費目別寄与度 は大きい方から原材料費，家族労貨見積額，種菌費の 順である。これらについて差異分析を行らと表 4 のよ らになる．雇用労働がかなり導入されているために表 では家族労貨見積額に支払い労貨を加えた労働費につ いて分析している。さて，混合差異を除いて菌床価額 格差の要因を分析すれば，最も大きな要因として労働 費の価格差異が, 次いでオガ費の価格差異, 種菌費の 価格差異があげられる，この他に注目されるのは，労 働費の数量差異がマイナスになっていることである. 参考に 2 力国間の価格差 $\left(\mathrm{P}^{\mathrm{J}} / \mathrm{P}^{\mathrm{C}}\right)$, 数量差 $\left(\mathrm{Q}^{\mathrm{J}} / \mathrm{Q}^{\mathrm{C}}\right)$, 価

表 $3.1,000$ 個当たり菌床価額格差

\begin{tabular}{|c|c|c|c|c|}
\hline 費 & 日 本 & 国 & 格 差 & 寄与 \\
\hline 種 & $\begin{array}{c}\text { 円 } \\
79\end{array}$ & 円 & $\begin{array}{c}\text { 円 } \\
32,138\end{array}$ & $\begin{array}{r}\% \\
4.9\end{array}$ \\
\hline 費 & 581 & & & 0.2 \\
\hline 材 料 & 652 & & 39 & 27.2 \\
\hline 機 & 0 & 23 & -23 & 0.0 \\
\hline 光 熱 水 道 費 & 076 & 639 & & 0.9 \\
\hline 支払 労 貢 & 0 & & & -0.6 \\
\hline 借 料 & 70 & 23 & & 13.3 \\
\hline 減 価 償 却 費 & 38 & 0 & 38 & 2.8 \\
\hline 家族労兵見積額 & & & & 25.3 \\
\hline 投下資本利子見積額 & 14,436 & 8 & 18 & 6.0 \\
\hline 計 （菌㦿 価 額） & 32,074 & 842 & 15,232 & 00.0 \\
\hline
\end{tabular}

資料：’93年度分聴き取り調査結果.

注：1）「日本」は奈良県の 1 事例で，「中国」は16戸平 均である。

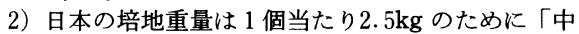
国」の数值は $2.5 \mathrm{~kg}$ 換算の数值である.

3）「格差」は「日本」から「中国」を差し引いて算 出している。 
表 4.1,000個当たり菌床価額の差異分析

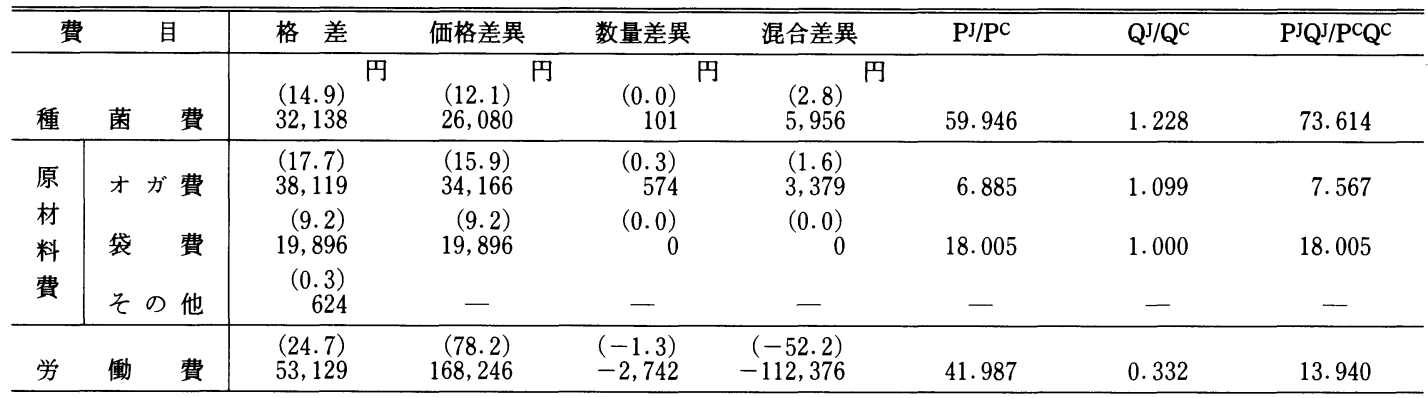

資料：表 3 と同し．

注：1）表 3 の注 1）から 3）を参照.

2）「格差」椚から「混合差異」閵の上段（）内は表 3 の菌床価額格差に対する寄与度（\%）を示す.

3）「労働費」は家族労梖見積額と支払い労貨を加えて算出している.

4）「一」は資料に基づいて算出ができないことを示す.

額差 $\left(\mathrm{P}^{\mathrm{J}} \mathrm{Q}^{\mathrm{J}} / \mathrm{P}^{\mathrm{C}} \mathrm{Q}^{\mathrm{C}}\right)$ を示している. 労働費の数量差が1. 0以下になっている.

3 ）乾シイタケ生産 表 5 亿乾シイタケ $\mathrm{kg}$ 当たり 生産費の費目別格差を示している．生産費格差に対す る寄与度が大きい費目はほだ木償却費・菌床費と家族 労貨見積額である．ほだ木償却費・菌床費の格差をさ
らに詳しくみたものが表 6 である. $\mathrm{kg}$ 当たりほだ木 償却費・菌床費の格差に最も大きく寄与しているのが 家族労兵見積額で, 次に種菌費である. 種菌費につい ては, 中国では「原種」と呼ばれる菌を購入して自家 で培養して「生産種」をつくり，この「生産種」を培 地に接種するのに対して日本では純粋培養したオガ菌

表 $5 . \mathrm{kg}$ 当たり生産費の費目別格差

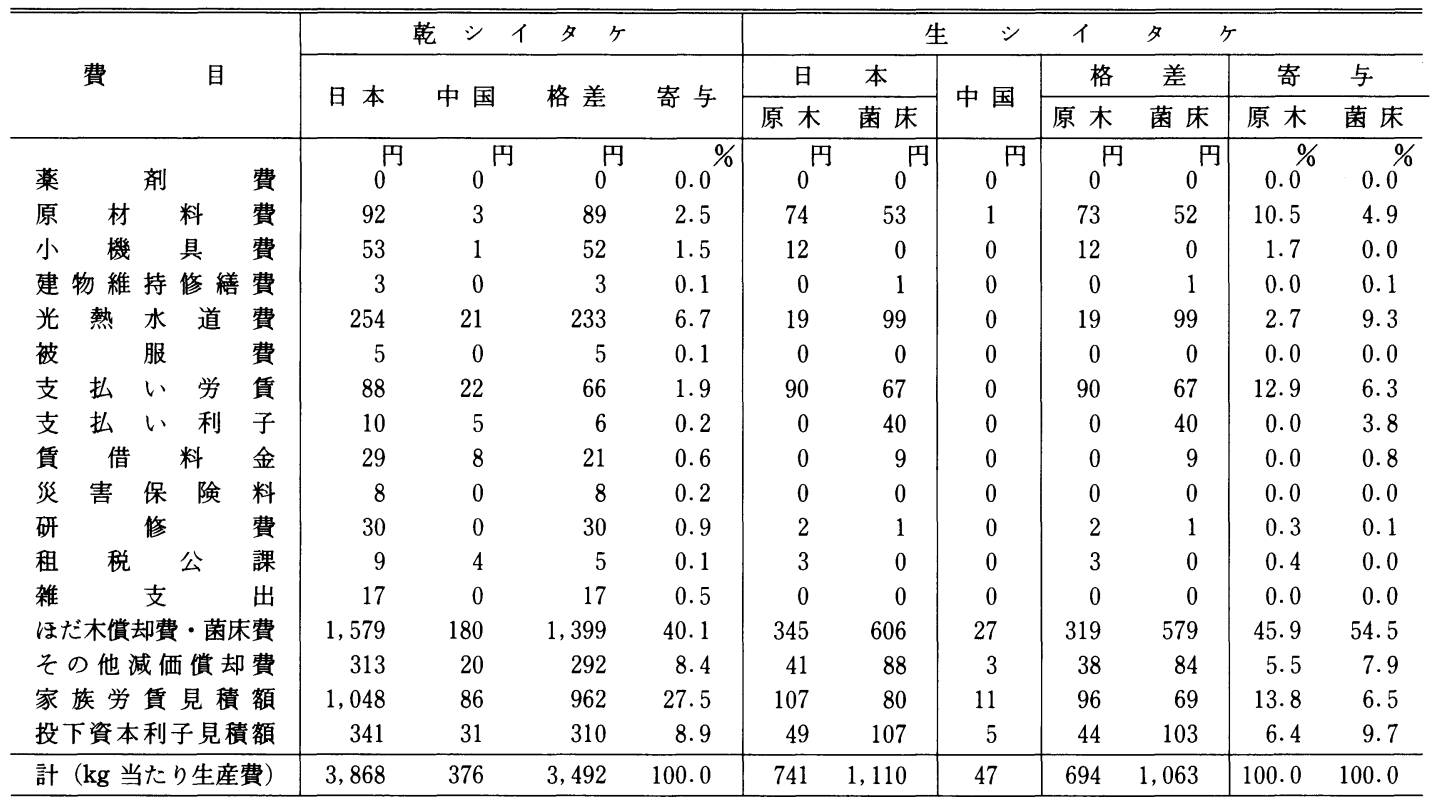

資料：表 2 と同じ.

注：1）表 2 の注 1）2）3）5）および表 3 の注 3）を参照.

2）費用は小数第 1 位を四捨五入して示す.

3）「計 ( $\mathrm{kg}$ 当たり生産費)」を算出する場合には支払い利子は投下資本利子見積額に含んでいる.

4）「ほだ木償却費・菌床費」は乾シイタケ生産を含めて原木栽培ではほだ木侻却費を, 日本の菌床栽培では菌床購入原価 を, 中国では菌床価額（生産費用）を示す. 
表 $6 . \mathrm{kg}$ 当たりほだ木償却費・菌床費格差

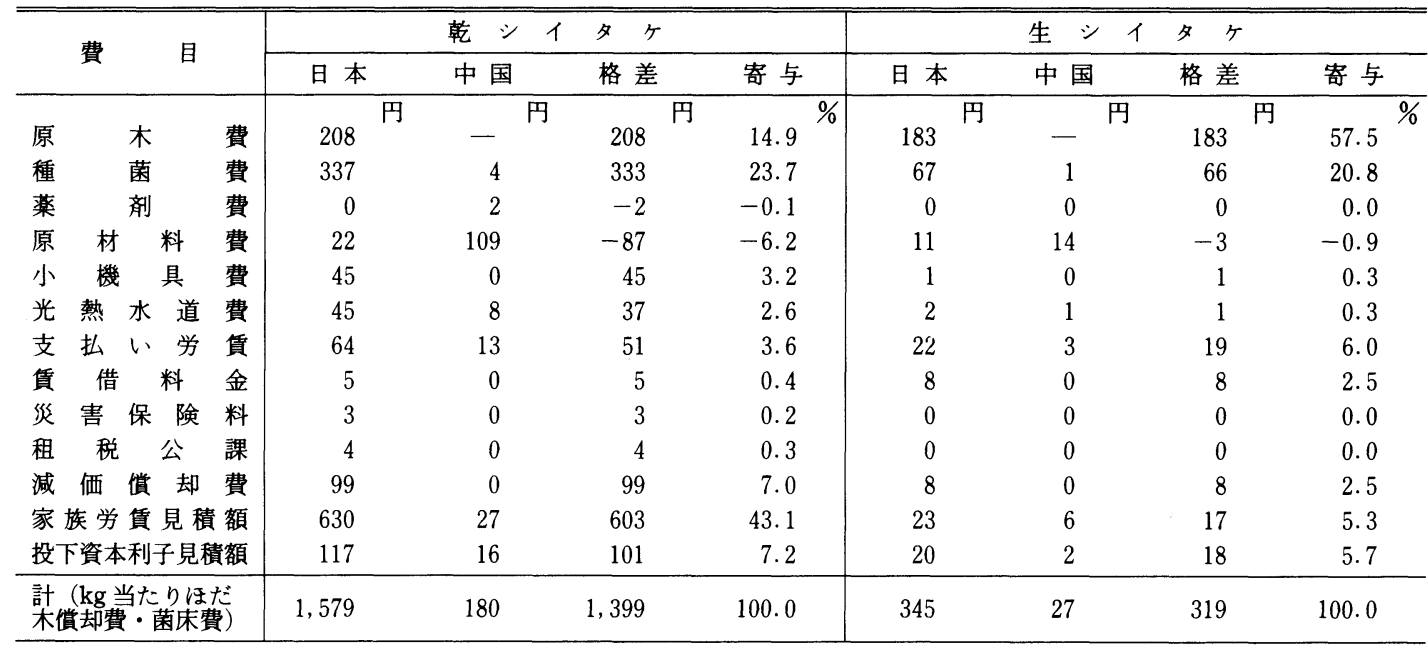

資料: 表 2 と同じ.

注：1）表 2の注 1）2），表 3 の注 3）および表 5 の注 2）を参照.

2)「日本」は原木栽培を示す.

3）「計（kg 当たりほだ木償却費・菌床費）」は「日本」では’93年のほだ木価額に基づいて算出した $\mathrm{kg}$ 当たりほだ木償却 費を，「中国」では $\mathrm{kg}$ 当たり菌床価額を示す.

4）「中国」欄の「一」は該当する費目がないことを示す.

または種駒を購入して原木に植菌する。したがって， 数量差異を算出することが困難なために差異分析を行 らことができない，また，中国では培地材料としてオ ガを用いているが，これは表の原材料費に計上してい るために原木費は日本だけに計上されている。そこ で, 表 7 に労働費の差異分析結果だけを示している. ほだ木償却費・菌床費の労働費格差は「ほだ木育成・ 培養過程」欗に示している. 家族労兵見積額ではなく
労働費の差異分析を行っている理由は菌床価額の分析 と同じである．表から $\mathrm{kg}$ 当たり生産費格差には洼だ 木育成過程または培養過程を含めた労働費の価格差異 がもっとも寄与していることがわかる.この他に労働 費の数量差異はマイナスになっていることが注目され る.これは日本の機械乾燥と中国の天日乾燥の違いか らきている。

4 ）生シイタケ生産 まず，日本の原木栽培と中国

表 $7 . \mathrm{kg}$ 当たり労働費・菌床費の差異分析

\begin{tabular}{|c|c|c|c|c|c|c|c|c|c|c|}
\hline \multicolumn{4}{|c|}{ 項 } & 格 差 & 価格差異 & 数量差異 & 混合差異 & $\mathrm{P} / \mathrm{P}^{\mathrm{C}}$ & $\overline{\mathrm{Q}^{\mathrm{J}} / \mathrm{Q}^{\mathrm{C}}}$ & $\mathrm{P}^{\mathrm{J}} \mathrm{Q}^{\mathrm{J}} / \mathrm{P}^{\mathrm{C}} \mathrm{Q}^{\mathrm{C}}$ \\
\hline \multirow{2}{*}{$\begin{array}{l}\text { 労 } \\
\text { 働 }\end{array}$} & 乾 & \multicolumn{2}{|c|}{$\begin{array}{l}\text { シイタヶ生産過 程 } \\
\text { ほだ木育成・培養過程 }\end{array}$} & $\begin{array}{c}(29: 4) \\
1,028 \\
(18.7) \\
654\end{array}$ & $\begin{array}{c}(120.5) \\
4,207 \\
(36.5) \\
1,275\end{array}$ & $\begin{array}{c}(-2.3)^{\text {円 }} \\
-79 \\
(-0.5) \\
-19\end{array}$ & $\begin{array}{c}(-88.7) \\
-3,099 \\
(-17.2) \\
-602\end{array}$ & $\begin{array}{l}40.143 \\
32.451\end{array}$ & 0.528 & 10.558 \\
\hline & \multirow[t]{2}{*}{ 生 } & $\begin{array}{l}\text { 原 } \\
\text { 木 }\end{array}$ & $\begin{array}{l}\text { シイタケ生産過 程 } \\
\text { ほだ木育成・培養過程 }\end{array}$ & $\begin{array}{c}(26.7) \\
185 \\
(5.2) \\
36\end{array}$ & $\begin{array}{c}(66.4) \\
461 \\
(59.8) \\
415\end{array}$ & $\begin{array}{c}(-1.0) \\
-7 \\
(-1.2) \\
-8\end{array}$ & $\begin{array}{c}(-38.8) \\
-269 \\
(-53.5) \\
-371\end{array}$ & 41.686 & 0.416 & 17.341 \\
\hline 費 & & 菌 & 床 & $\begin{array}{r}(12.8) \\
136\end{array}$ & $\begin{array}{r}(43.7) \\
464\end{array}$ & $\begin{array}{c}(-0.8) \\
-8\end{array}$ & $\begin{array}{c}(-30.1) \\
-320\end{array}$ & 42.052 & 0.310 & 13.036 \\
\hline & 菌 & & 林 & $\begin{array}{r}(54.5) \\
579\end{array}$ & $\begin{array}{r}(76.4) \\
812\end{array}$ & $\begin{array}{c}(-0.7) \\
-7\end{array}$ & $\begin{array}{r}(-21.3) \\
-226\end{array}$ & 31.488 & 0.722 & 22.734 \\
\hline
\end{tabular}

資料：表 2 と同じ.

注：1）表 2 の注 1）から4）および表 3 の注 3）を参照.

2）「原木」は原木栽培を指している.

3）「格差」欗から「混合差異」椚の上段（）内は表 5 の $\mathrm{kg}$ 当たり生産費格差に対する寄与度（\%）を示す.

4）「菌床費」は 2 力国間の菌床栽培の差異分析を示す．表 5 の注 4) を参照. 
とを比較してみる．表 5 に $\mathrm{kg}$ 当たり生産費の費目別 格差を示している．生産費格差に対する寄与度が大き い費目はほだ木償却費・菌床費, 家族労兵見積額, 支 払い労貨の順となる。このうちほだ木償却費・菌床費 の格差を詳しくみたるのが表 6 である．原木費，原材 料費，種菌費の表示方法は乾シイタケ生産と同じであ る.したがって, 原木費, 種菌費を除いてみると寄与 度に大きなバラッキはない，注目されるのは家族労貨 見積額の格差が少ないことであるが，支払い労貨と合 わせて労働費としてみた場合には格差に対する寄与度 は比較的大きい，そこで，表 7 亿労働費の差異分析結 果を示している．表示方法は乾シイタケ生産と同じで ある. 表から $\mathrm{kg}$ 当たり生産費格差には労働費の価格 差異が最も寄与していることがわかる。また，「ほだ 木育成・培養過程」椚の数量差異や数量差 $\left(\mathrm{Q}^{\mathrm{J}} / \mathrm{Q}^{\mathrm{C}}\right)$ か ら，機械化による省力化によって労働費の格差は価格 差異よりかなり樎小されることがわかる.

次に，菌床栽培間の比較であるが，表 $5 に \mathrm{~kg}$ 当た り生産費の費目別格差を示している．生産費格差に対 する寄与度が大きい費目は菌床費である．この菌床費 は, 日本ではK方式のために菌床の購入原価が，中国 では自家培養に要した生産費用が示されている. 菌床 費の次に投下資本利子見積額と光熱水道費の寄与度が 大きい。これは日本の栽培方法が空調施設型であるた めである．また，家族労賃見積額や労働費の寄与度が 乾シイタケ生産や生シイタケ生産の原木栽培に比べて 小さいことが注目される，そこで，菌床費とともに労 働費の差異分析結果を表 7 に示している. $\mathrm{kg}$ 当たり 生産費格差には菌床費の価格差異が最も寄与している ことがわかる．労働費の価格差異の寄与度も大きい． 低貨金の労働と低価格のオガによって自家培養した方 が安く菌床を調達できることを示しているが，菌床費 の数量差異はマイナスである. 労働費格差が小さいの は表 7 の「菌床栽培」欄の数量差異や数量差 $\left(\mathrm{Q}^{\mathrm{J}} / \mathrm{Q}^{\mathrm{C}}\right)$ に示すように，日本では施設化によって省力化が図ら れているためである.

表 7 の数量差 $\left(\mathrm{Q}^{\mathrm{J}} / \mathrm{Q}^{\mathrm{C}}\right)$ の逆数が労働や菌床の物的生 産性の格差をあらわす．物的生産性の格差は1.0以上 の数値となって生産性は日本が中国を上回っている. 労働費や菌床費の価格差が大きいことが生産費格差の 要因となっている．日本のシイタケ栽培経営では生産 費格差の縮小，すなわち生産費低减のために機械化や 施設化によって省力化を四ることが考えられる．乾シ イタケ生産では傾斜地を利用しているために機械化・ 施設化は限られてくるが，労働日数が多い、ほだ木育成
過程における省力化技術の開発が必要である．価格差 $\left(\mathrm{P} / \mathrm{PC}^{\mathrm{C}}\right)$ をみると, 省力化による $\mathrm{kg}$ 当たり生産費の低 减によって日本の生産費が中国の生産費を下回ること はないが，生産費低減は次の 3 点から重要である。 ず，安い中国産の輸入に上る価格低迷は今後も続くこ とである，価格低迷下で収益性を向上させるためには 生産費の低隇が必要である. 第 2 にバブル崩壊後, 消 費者はできるだけ安い農産物の提供を望んでいるの で，これに対応して可能な限り生産費の低隇に努める 必要がある. 第 3 に経営環境の変化として高龄化があ げられ，これに対応していくためには省力化がキー ワードとなる。 また，菌床メーカーは規模の経済性を 活かしてできる限り安く菌床を生産農家に提供する必 要がある.

なお，前述したように中国の生シイタケ生産では生 産技術が確立していないが，仮に近い将来現在の要素 投入量で生産量が培地重量の $30 \%$ まで增加したとして も中国の物的生産性が日本を上回ることはない。した がって, 上述した日本の生産費低減の方向に誤りはな い.

\section{5. おわりに}

最後に, 中国のシイタケ栽培の将来性について述べ ておきたい，換言すれば，生産技術の普及による新規 参入と規模㧪大の可能性についてであるが，新規参入 と規模拡大の大きな要因はシイタケ栽培部門の収益性 が相対的に高いことである。中国のシイタケ栽培部門 の収益性は, $\mathrm{kg}$ 当たりの生産費が販売手取単価を上 回っている. この要因として, 販売手取単価の低迷と インフレによる生産資材の高騰があげられる. 眅売手

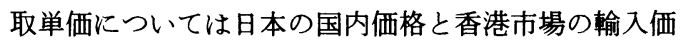
格が大きく影響している．現在の輸入量と国内生産量 からみて近い将来日本の国内価格が上昇する可能性は 少ない，また，香港市場においても中国産畭シイタヶ の急増によって輸入価格は低迷している. 他方, イン フレによる生産資材価格の上昇は激しい，菌床の原材 料をみると,オガが1.5倍（'94年/'90年），フスマが 2.3 倍 (同), 砂糖が 2.7 倍 (同), ビニールが 1.4 倍 (同) の価格上昇を示している27).このインフレは今後も続 くと考学られている. したがって，今後さらにシイタ ケ栽培部門の収益性は低下していくであろら ${ }^{28)}$ 。しか し, 他の生産部門よりる相対的に収益性が良ければシ イタケ栽培部門に参入したり，規模拡大していく。そ こで, 調査農家の稲作の収益性をみると 1 日当たり家 族労働報酬は187円となって扤り，現状ではシイタケ 
栽培の収益性の方が低い、シイタケ栽培は冬場中心の ために稲作にかわることはないが，収益性の高い新し 、生産部門の導入を考えることができる，しかし，山 間地で消費地までの交通網が未発達なために商品化で きる作目はかなり限られるので，今後も所得確保のた めに継続してシイタケ栽培，とくに貯蔵性がある乾シ イタケ生産が行われると考学られる．ただし，上述し た理由によって収益性が悪化しているためにシイタヶ 栽培部門に新規に参入したり，規模扗大する栽培農家 は一部の高い生産技術をもった栽培農家を除いて今後 しばらくないであらら。したがって，これまでのよら な日本のシイタケ輸入量の増加傾向は考えられない29). 調査農家16戸に行った経営の意向調査でもこの検討結 果と同じ結果を得ている.すなわち, 意向調査結果で は「将来，シイタケ栽培をやめる」が 1 戸で，将来も 継続して行らが規模は，(1)「縮小」が 3 戸で，(2)「現 状維持」が 3 戸で，(3)「わからない」が 6 戸で，(4)「払 大」が 2 戸である30)．規模を「縮小」「現状維持」「わ からない」が大きな割合を占めていることからシイタ ケ栽培農家が収益性の低下傾向を感じており，今後の シイタケ販売単価や生産資材価格の動向に注目してい ることがらかがえる。

今日まで中国の地域振興に大きな役割を担ってきた シイタケ栽培であるが，販売手取単価の低迷が 1 要因 となり収益性が低下している．販売手取単価低迷の原

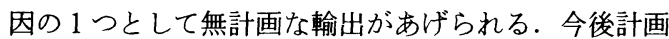
的な生産と輸出が必要である。さらに詳しい中国のシ イタケ振興策については別の機会に述べたい。

注 1）大蔵省『日本貿易統計』に基づく，なお，乾シイタタ と生シイタケの生産量については乾シイタヶ換算と明 記している箇所を除いて，それぞれの生産物の重量で 示す.

2）本文で倍数表示してあるもののらち整数部分 2 ケタの ものは小数第 1 位を，また整数部分 1 ケタのものは小 数第 2 位を四捨五入している.「約」または「およそ」 の表現はしていない。

3）林野庁林産課『特用林産関係資料（部内資料)』に基 づく.

4）本文で\%表示している数值は（\%表示で）小数第 1 位 を四捨五入している。「約」または「扰よそ」の表現 はしていない。

5）国際競争力を決定づける基本的要因として生産費があ ることは多くの文献に拈いて述べられている．例えば 文献〔4][8]がある．したがって，本稿では生産 費が国際競争下でなぜ重要であるかの理論的展開まで は行っていない.
6）概況のちち，(1)自然的立地条件は文献 [5]に，(2)総 生産量のらち中国のものは文献 [5] に, 慶元県のも のは文献〔7]（'86年分）と聴き取り調査（'86年分 以外）に, (3)生産額は文献 [5] 飞, (4)人口, 農家戸 数, 職業別戸数, 乾シイタケ市場は文献 [7]に基づ $<$.

7）7,000戸はシイタケ栽培農家戸数に含まれていると考 えられる。

8）耕地面積は各地目について所有していない農家を含め て16戸の平均を示している。

9）16戸平均 1,000 個当たり生産量は $63.7 \mathrm{~kg}$ である. し たがって，1 戸当たり規模は 3,603 個（= $(6,886$ 千 $\mathrm{kg} / 63.7 \mathrm{~kg}) / 30,000$ 戸) となる.

10）稲作においても耕起・整地作業や代かき作業を中心に 畜力である牛を飼養している農業者を畜力と共に雇い 入れている. 雇用労働日数は総労働日数（1戸当たり 平均 64.0 日）の $7 \%$ に相当する.

11）(1)中国に占める生産量の割合，(2)農家に占めるシイタ ケ栽培農家の割合, (3)シイタケ栽培部門の経営におけ る役割, (4)乾シイタケ市場の存在の 4 点から慶元県は 中国を代表するシイタケ主産地といえる.

12）「乾専」とはシイタケ販売金額掞よび生産量の $90 \%$ 以 上を乾シイタケが占めている栽培形態を，「乾主生従」 とはシイタケ販売金額の $50 \%$ 以上 $90 \%$ 未満および生産 量の $50 \%$ 以上を乾シイタケが占めている栽培形態を, 「生主乾従」とはシイタケ販売金額の $50 \%$ 以上 $90 \%$ 未 満および生産量の $50 \%$ 以上を生シイタケが占めている 栽培形態を、「生専」とはシイタケ販売金額の $90 \%$ 以 上拉よび生産量の $50 \%$ 以上を生シイタケが占めている 栽培形態をいう，中国の「生専」の生産農家は生シイ タケを乾シイタケ生産農家に売っている場合がかなり ある。

13） 1 日 8 時間労動で換算している. また，作業別労働日 数を算出できた13戸の平均値である.

14）作業別労働日数を算出できた栽培農家の平均である. 乾シイタケ生産は 6 戸, 生シイタケ生産は 5 戸の平均 值である.

15）文献 [1]pp. 34〜38 を参照.

16）文献 [2]を参照

17）奈良県の事例では 5 月から 7 月は茶栽培に専念するた めに生シイタケ生産は行わない.

18）農業臨時雇兵金と一般サラリーマンの年収は聴き取り 調査に基づく.

19）文献 [2]pp. 73〜 75 を参照.

20）文献 [6] p. 433 を引用.

21）文献 [8] p. 2 を引用.

22）文献 [8] p. 79 を引用.

23）文献 [9] [10]がある.

24）文献〔8]がある.

25）文献 [3]がある

26）文献 [8] p. 80 を引用.

27）生産資材価格は生産資材販売店への聴き取り調査に基 づく. 
28）生シイタケ生産で生産技術の確立があっても，激しい インフレが続けば長期的には収益性は低下すると考兄 られる.

29）中国においてシイタケ販売価格の上昇があるとすれば 所得の増大に伴う中国国内の消費量が増加したときで あるが，統計資料がないためにそこまで言及していな い. 本稿ではこれまでのような輸出の増加が続かない ことだけを述べている.

30）調査農家16戸のうち 1 戸は無回答である.

\section{参考および引用文献}

[1]古塚秀夫『シイタケ栽培経営管理論』, 明文書房, 1992.

〔2〕古塚秀夫・錦織照彦「生シイタケ生産の現状と課題」, 『鳥取大学農学部研究報告』第 48 号, pp. $71 \sim 77$.

[3]稲本志良「第 3 章低コスト稲作の舞台裹一経営と技術 一」, 亀谷 是『米輸出大国・タイ米産業の光と影』 富民協会, 1991, pp. 78 101.

〔4]刍谷 是・辻井博「アメリカ合衆国に扣ける米生産 の計測手法に関する研究」、農業計算学研究」第19号, pp. $17 \sim 41$.

[5]慶元県第 2 届香菇祭組委会「慶元香菇情況介紹」, 1993.
[6]岡本 清『原価計算』, 国元書房, 1992 .

[7]浙江省慶元県農村経済委員会・工商行政管理局（編） 「中国第一大菇市一慶元香菇市場」, 1992.

[8]生源寺真一・David C. Price『酪農のコスト及び生産 性に関する日英比較研究』, 1989 .

[9]过井博「米生産費と米価の国際比較」, 『農業と経 済』, 第 52 巻第 4 号, pp. 16 27.

〔10]辻井 博「第 2 章アメリカ版米食管と輸出戦略」, 亀 谷 是『アメリカ米産業の素顔』, 富民協会, 1988, pp. $28 \sim 52$.

〈付記〉

本稿を仕上げるに当たり京都大学名誉教授頼平 先生から懇切なご指導を賜った。また，鳥取大学農学 部松原茂昌先生からは貴重な資料の提供を受けた。さ らに中国の調査では蔣 時文君（現山形大学大学院）, 細野晃史君（現彦根市役所産業部）に労を煩わせた。 記して深勘なる謝意を表するものである.

（筆者：鳥取大学晨学部, 浙江省慶元県㬓村経済委員 会） 